\title{
The contribution of landscape features, climate and topography in shaping taxonomical and functional diversity of avian communities in a heterogeneous Alpine region
}

\author{
Matteo Anderle ${ }^{1,2}$ D $\cdot$ Chiara Paniccia ${ }^{1} \cdot$ Mattia Brambilla ${ }^{3} \cdot$ Andreas Hilpold $^{1} \cdot$ Stefania Volani $^{1} \cdot$ Erich Tasser $^{1}$. \\ Julia Seeber $^{1,2} \cdot$ Ulrike Tappeiner $^{1,2}$
}

Received: 4 September 2021 / Accepted: 6 February 2022 / Published online: 22 February 2022

(c) The Author(s) 2022

\begin{abstract}
Understanding the effects of landscape composition and configuration, climate, and topography on bird diversity is necessary to identify distribution drivers, potential impacts of land use changes, and future conservation strategies. We surveyed bird communities in a study area located in the Central Alps (Autonomous Province of South Tyrol, northeast Italy), by means of point counts and investigated taxonomic and functional diversity at two spatial scales along gradients of land use/land cover (LULC) intensity and elevation. We also explored how environmental variables influence bird traits and red-list categories. Models combining drivers of different types were highly supported, pointing towards synergetic effects of different types of environmental variables on bird communities. The model containing only LULC compositional variables was the most supported one among the single-group models: LULC composition plays a crucial role in shaping local biodiversity and hence bird communities, even across broad landscape gradients. Particularly relevant were wetlands, open habitats, agricultural mosaics made up of small habitat patches and settlements, ecotonal and structural elements in agricultural settings, and continuous forests. To conserve bird diversity in the Alps, planning and management practices promoting and maintaining small fields, structural elements, and a mosaic of different LULC types should be supported, while preserving continuous forests at the same time. Additionally, pastures, extensively used meadows, and wetlands are key to conservation. These strategies might mitigate the impacts of global change on bird diversity in the Alps and in other European mountain areas.
\end{abstract}

Keywords Agriculture intensification · Avian conservation · Habitat type $\cdot$ Landscape homogenisation $\cdot$ Land abandonment

\section{Introduction}

Worldwide, biodiversity has been declining more rapidly in the last decades than at any time in recent human history (Barnosky et al. 2011), and anthropogenic land use/ land cover (LULC) changes have had extreme impacts

Communicated by Yanyun Zhang.

Matteo Anderle

matteo.anderle@eurac.edu

1 Institute for Alpine Environment, Eurac Research, Drususallee/Viale Druso 1, 39100 Bolzano/Bozen, Italy

2 Department of Ecology, University of Innsbruck, Sternwartestrasse 15/Technikerstrasse 25, 6020 Innsbruck, Austria

3 Dipartimento Di Scienze E Politiche Ambientali, Università Degli Studi Di Milano, via Celoria 26, 20133 Milano, Italy
(Newbold et al. 2015). Habitat loss and fragmentation are critical drivers of biodiversity declines, and largely result from agricultural intensification in favourable areas, or rural abandonment of marginal ones (Tasser et al. 2007; Newbold et al. 2015). Both these opposing processes lead to landscape homogenisation (Brambilla 2019), resulting in severe losses of habitat diversity (Kujawa et al. 2020), and lower the beta diversity of animal communities (Burgess and Maron 2016). Habitat fragmentation negatively influences abundance, movements, and persistence of many bird species (Villard et al. 1999) by disrupting connectivity between habitats (Amini Tehrani et al. 2020) and reduces native biodiversity and ecological integrity (Noss and Cooperrider 1994). Moreover, habitat loss and fragmentation also affect functional diversity (Flynn et al. 2009).

Understanding the impacts of habitat loss and fragmentation on biodiversity is therefore essential. However, several driving factors (e.g., topography, climate, landscape 
composition or configuration) contribute synergistically or antagonistically to biodiversity patterns. These drivers and their relative changes often act together, making it difficult to disentangle overlapping effects (de Chazal and Rounsevell 2009). Also, effect predictions may change at different spatial scales, both in terms of landscape attributes (Debinski et al. 2001) and climate (Brambilla et al. 2019). Only few studies evaluated the combined effect of factors (Barras et al. 2021; Ceresa et al. 2021), whereas most studies focused on single factors (Cabral et al. 2021) or single habitats (Jacoboski and Hartz 2020). Specifically, LULC and climate change are mostly investigated separately, resulting in a high risk of over- or underestimating their relative influence (de Chazal and Rounsevell 2009). Thus, detailed information on LULC effects on species abundance and functionality, simultaneously considering climate and topography, is required to accurately predict the effects of LULC changes and disentangle their importance for biodiversity from other drivers (Brambilla et al. 2020a). This combined approach is also key to effective conservation and management (Doley 2010), as is the evaluation of landscape composition or configuration effects over environmental gradients (Rüdisser et al. 2012). This is particularly relevant in mountain landscapes, where elevation gradients shape complex environments (Liu et al. 2018), even though this has rarely been explored (Amini Tehrani et al. 2020). In the European Alps, a biodiversity hotspot hosting several endemic species (Jenkins et al. 2013), LULC changes are occurring along broad elevation gradients, and across very different environments (Pecher et al. 2013).

In this study, we assess the effects and the importance of landscape composition and configuration, climatical and topographical drivers, on bird functional and taxonomic diversity across different landscapes and elevation gradients in the Alps. Birds are a diverse, well known and easily censused group, that are excellent indicators for global biodiversity trends (BirdlifeInternational 2020). Birds play an essential role in key ecological processes, including seed dispersal, pollination, pest control, nutrient cycling, and scavenging (Sekercioğlu et al. 2016). They are highly sensitive to environmental changes, and respond quickly to habitat alteration, including climate and LULC changes (Regan et al. 2015; Sekercioğlu et al. 2016; Scridel et al. 2018). To investigate the effects of environmental drivers on biological communities by combining functional and taxonomic diversity metrics offers a broader understanding of such effects and of potential consequences for ecosystem functions (Siriwardena et al. 2019; Jacoboski and Hartz 2020).

In this study, we aim to investigate how LULC, climatical, and topographical drivers shape bird diversity in European mountain landscapes. Specifically, we want to understand (1) which of these factors exert the strongest effects, and

(2) how they impact bird diversity, as well as to address (3) how those drivers select for specific traits and are related to different threat level according to bird red-list categories. Understanding the impact of LULC patterns on biological community structure, taxonomic and functional diversity, is key to the effective management of changing ecosystems (Lee and Martin 2017), and is particularly urgent for a biodiversity hotspot undergoing important transformations such as the Alps (Payne et al. 2017).

\section{Materials and methods}

\section{Study area and study sites}

The study was carried out in the Autonomous Province of South Tyrol (Italy), in the Central Alps (Fig. 1). It extends over approx. $7400 \mathrm{~km}^{2}$, with a broad elevation range (194-3905 m a.s.1.). Landscapes comprise forests (42.7\%), natural and seminatural lands such as alpine grasslands, rocks, freshwater habitats and glaciers (overall 39.6\%), intensive agricultural land (13.4\%), while settlements are rather limited (4.3\%). Most agricultural areas are meadows (64.3\%), followed by orchards (19.1\%), pastures $(6.3 \%)$, vineyards (5.6\%), and annual crops (3.9\%). Crops are mainly located in valley bottoms, whereas meadows and pastures are found from mountainsides to the subalpine and alpine belts. Data were collected in the framework of the project Biodiversity Monitoring South Tyrol (BMS 2021). According to the main habitats 168 study sites were selected by a stratified and random site-selection approach (see BMS 2021 and Fig. 1).

\section{Bird survey}

We surveyed bird communities by means of 10 -min pointcounts (Bibby 2000; Sutherland 2006), considering all birds within a $100 \mathrm{~m}$-radius from the site (Fornasari and Mingozzi 1999). To avoid double counting of the same individuals, the minimum distance between neighbouring sites was set at $800 \mathrm{~m}$. Surveys were carried out between mid-April and mid-July in 2019-2020, depending on local conditions. Every year we sampled the same number of sites per habitat type (see BMS, 2021). We started earlier in valley-bottom sites and later in the Alpine sites, as bird breeding season starts later with increasing elevation (Assandri et al. 2017a; Ceresa et al. 2020b). Counts started shortly after sunrise (5.30 a.m.), and were completed before 11 a.m. For sites at lower elevations we performed three visits, but only two for upland sites (subalpine or alpine) because of the much shorter breeding season at higher elevation. Between subsequent visits, at least 15 days passed, and the order of sitesurveys was changed. Adverse weather conditions (moderate/strong wind or heavy rain/snow) were avoided. 


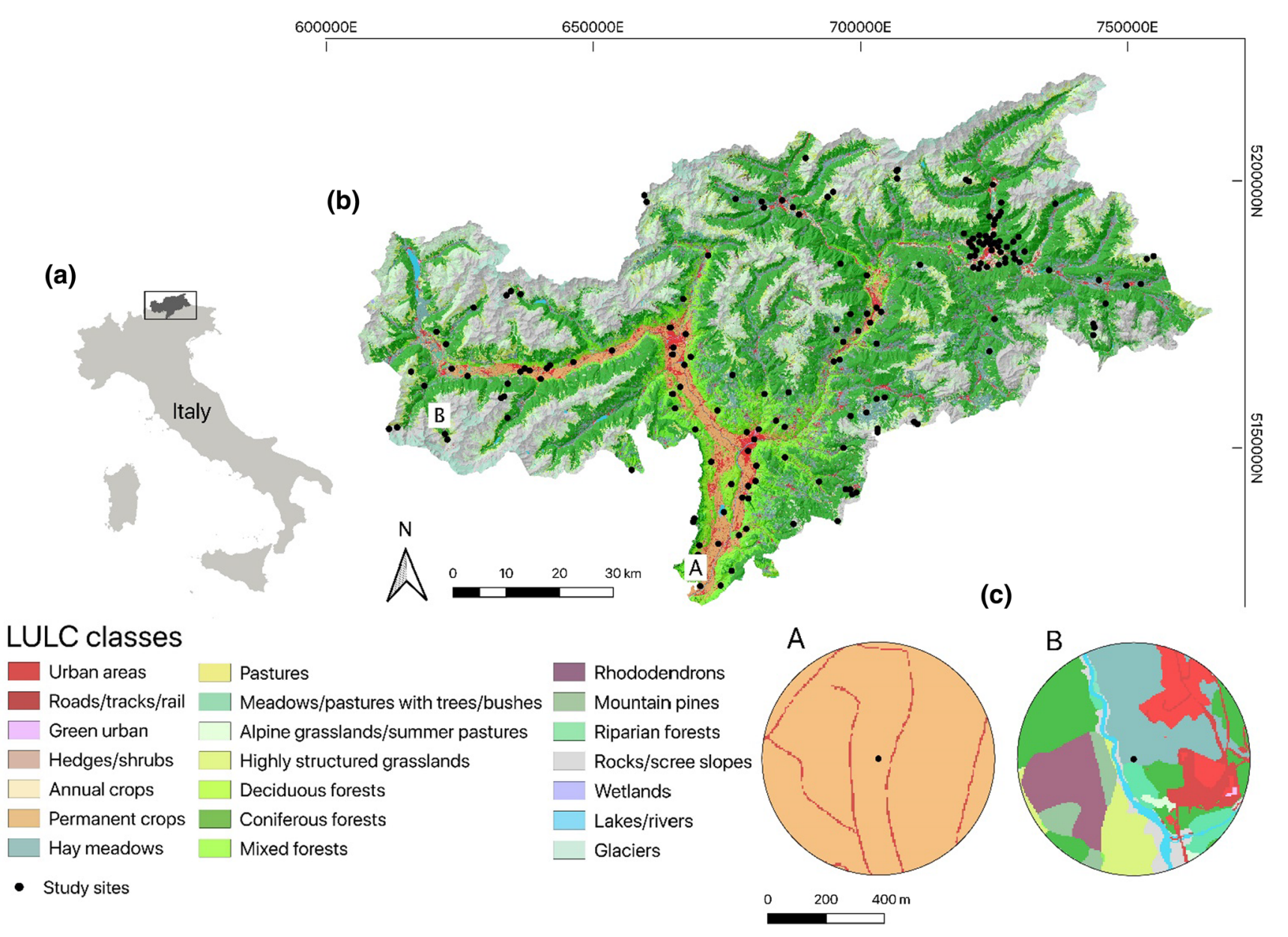

Fig. 1 a Autonomous Province of South Tyrol in Italy, b the 168 study sites, $\mathbf{c}$ two landscape examples (A and B) showing the spatial details of land use/land cover (LULC) mapping

\section{Bird traits}

Species-trait approaches focus on functional aspects of biodiversity, and constitute an additional tool to the traditional taxonomic approach (Siriwardena et al. 2019; Jacoboski and Hartz 2020). Following previous studies (Jacoboski and Hartz 2020; Altamirano et al. 2020), we selected traits that can affect species' ability to respond to habitat changes (e.g., landscape homogenisation may select for species with smaller size, a generalist diet, shorter generation time, and higher dispersal abilities). The traits considered were diet, foraging substrate, mean body mass, broods per year, nest type, habitat use during breeding season, territoriality, migration strategy, and specialization. We also included the red-list categories of birds, using threat categories from the Red List of 2020 for birds breeding in South Tyrol (Ceresa and Kranebitter 2020). See Table S1 for sources and full descriptions of traits.

\section{Bird diversity indices}

We removed records related to species observed only flying over sites or occurring exclusively as migrants (Table S2). A functional dispersion index (Fdis, Laliberté and Legendre 2010) was calculated using the avian traits, based on foraging behaviour, morphology, ethology, and breeding behaviour (Kim et al. 2020). We used Fdis, calculated using the ' $F D$ ' package in $\mathrm{R}$ (Laliberté et al. 2014), to describe the overall functional diversity in the community, since it measures the mean distance of species in a community to the centroid of all species in that community, being less affected by extreme values than other functional indices. Bird species richness (Sric) was calculated from the total number of species observed at each site during all visits. For calculating the Shannon diversity index (Shan) we chose the observation with the highest number of individuals per species out of all visits at a given site to avoid double count of the same individual 
during multiple visits. Sric and Shan were calculated using the 'Vegan' package in R (Oksanen et al. 2020).

\section{Environmental variables}

We prepared a LULC map by integrating different sources (Table 1 and Table S5). The minimum mapping unit was $25 \mathrm{~m}^{2}$, and we differentiated the LULC into 21 classes potentially important for bird ecology in the Alpine region (Assandri et al. 2017b; Brambilla et al. 2020c). We considered three variable types (topo-climatical, compositional, and configurational) evaluated at two spatial scales, considering radii of $100 \mathrm{~m}$ (3.14 ha) and $400 \mathrm{~m}$ (50.24 ha) around each site. The small radius reflects the territory size of many passerine species, which often defend territories of a few hectares during the breeding season (e.g., Bocca et al. 2007; Brambilla and Ficetola 2012; Pestka et al. 2018), while the larger one reflects the wider home ranges of larger birds (e.g., Wiktander et al. 2001; Bocca et al. 2007). Furthermore, the effects of some factors may be scale-dependent (e.g., microclimate conditions or spatial configuration).

Following other studies (Veach et al. 2017; Amini Tehrani et al. 2020) topo-climatical variables included: elevation, slope, potential solar radiation, mean annual precipitation, mean spring precipitation, and mean annual temperature. Landscape composition variables were estimated from the LULC map as the proportional cover of each LULC class. Following Fahrig et al. (2011), we selected Shannon diversity and Shannon evenness, the mean patch area, edge density and patch richness as configurational variables. Compositional and configurational variables were calculated using Fragstats 4.2 software (McGarigal 2015). See Table 1 for variable descriptions.

\section{Data analysis}

Following Zuur et al. (2010) we standardised all independent variables to better evaluate collinearity and relative responses (Cade 2015). We removed all variables with high collinearity (Spearman's Rho $\geq 0.68$, Dormann et al. 2013) from the database and at each modelling step we evaluated multicollinearity according to variance inflation factors (VIFs), and discarded the most problematic ones (VIF $>4$; Zuur et al. 2009, see Appendix S1). We built an accumulation curve using the 'iNEXT' package (Hsieh et al. 2016) to judge the sampling adequacy of our bird surveys for all sites (Fig. S7) as well as for the alpine and subalpine sites (Fig. S8).

We used a two-step approach, that allowed us to compare the support for different types of variables, and to find the most important variables within each type, while reducing the number of predictors at each step. Initially, we separately tested the effect of different types of variables on the three dependent variables Fdis, Shan, and Sric, at two spatial scales, using Linear Models (LM) for Fdis and Shan, and Generalised Linear Models (GLM) with a Poisson distribution for Sric (since these are count data; Zuur et al. 2013). At each step, we built all possible models with the dredge function in the R package 'MuMIn' (Barton 2020).

An information-theoretic approach was adopted to perform a model selection based on the Akaike's information criterion (Burnham and Anderson 2004), corrected for small sample size (AICc). As a first step, we selected the most supported models $(\triangle \mathrm{AICc}<2)$ within each type of predictors, after excluding uninformative parameters, i.e., those whose inclusion in the model resulted in an increase in the $\triangle \mathrm{AICc}$ value, even if the increase in AICc was lower than 2 (Arnold 2010). We carried out model averaging among the remaining models (all models with $\Delta$ AICc $<2$ ), or took the remaining unique, most supported model, if no other models showed similar support $(\Delta \mathrm{AICc}<2)$. In the second step, we selected from each group all the environmental variables included in the averaged or most supported model and re-ran the same procedure. We defined these models combining the most important predictors from all the different types as "synthetic models" (Assandri et al. 2017a; Brambilla et al. 2020a). We thus obtained six synthetic models (one for each dependent variable, at both scales), by averaging (full average) the most supported ones $(\Delta \mathrm{AICc}<2)$, or by taking the most supported if there were no alternative models with similar support (Fig. 2).

Finally, using the 'traitglm' function in 'mvabund' (Wang et al. 2012) we evaluated how the environmental variables included in the synthetic models influenced the presence of traits and red-list categories of bird species by adopting a model-based approach to the fourth-corner analysis (Brown et al. 2014). The fourth-corner model relates species traits and landscapes attributes by fitting a predictive model of species abundance as a function of matrices of environmental variables, species traits, and their interaction ('mvabund' R package; Wang et al., 2012). This method uses an extension of a GLM, fitting a single predictive model to all species across all sites simultaneously. Three matrices of environmental data, species abundance data, and species trait data were used to calculate a fourth matrix of trait-environment interaction coefficients, or fourth-corner terms (Wang et al. 2012). For visual interpretation we generated two heat-maps (one applied to traits and one to red-list categories), and used the LASSO penalty to remove interactions that failed to improve model fit (Wang et al. 2012). To test the statistical significance of the overall relationship between variables and trait or red-list category, we computed a Monte-Carlo randomisation test with 999 permutations (Wang et al. 2012). Lastly, we checked for potential patterns of spatial autocorrelation in model's residuals by means of a variogram (Dormann et al. 2007). Residuals showed no 
Table 1 Environmental variables descriptions, units, and whether they were tested in the model approach or discarded for high correlations. For references see Table S5

\begin{tabular}{|c|c|c|c|c|c|}
\hline Type & Variable & Name & Included & Description & Unit \\
\hline \multirow[t]{6}{*}{ Topo-climatical } & SolarRad & Potential solar radiation & Yes & $\begin{array}{l}\text { Sum of direct, diffuse, and reflected radia- } \\
\text { tion due to sun irradiance, according to } \\
\text { incidence solar angle, and the shadowing } \\
\text { effect of topography. It was computed } \\
\text { for a reference day ( } 21 \text { st June) using the } \\
\text { command r.sun in GRASS GIS (GRASS } \\
\text { Development Team 2020) }\end{array}$ & $\mathrm{Wm}^{-2}$ \\
\hline & TMAMme & Mean spring temperature & No & $\begin{array}{l}\text { Mean temperature March-June (mean of } \\
\text { daily temperature) }\end{array}$ & ${ }^{\circ} \mathrm{C}$ \\
\hline & TANNUALme & Mean annual temperature & No & $\begin{array}{l}\text { Mean temperature during the year (mean of } \\
\text { daily temperature) }\end{array}$ & \\
\hline & Elev & Elevation & No & $\begin{array}{l}\text { Elevation extracted by site using QGIS } \\
\text { (QGIS Development Team 2020) }\end{array}$ & m a.s.l. \\
\hline & Slope & Slope & Yes & $\begin{array}{l}\text { Mean slope within } 100 \text { and } 400 \text { m buffer } \\
\text { using QGIS (QGIS Development Team } \\
\text { 2020) }\end{array}$ & $\circ$ \\
\hline & AnnPrec & Mean annual precipitation sum & Yes & $\begin{array}{l}\text { Interpolated values of mean annual precipi- } \\
\text { tation sum (basis data: 1981-2010) }\end{array}$ & $\mathrm{mm} \mathrm{a}^{-1}$ \\
\hline \multirow[t]{21}{*}{ Compositional } & Glacier & Glaciers & No & \multirow{21}{*}{$\begin{array}{l}\text { Percentage of LULC classes within the } \\
\text { buffer }\end{array}$} & \multirow[t]{21}{*}{$\%$} \\
\hline & Urb & Urban areas & Yes & & \\
\hline & GreenUrban & Green urban & No & & \\
\hline & AlpGrass & Alpine grasslands and summer pastures & Yes & & \\
\hline & AlpShr & Highly structured grasslands & Yes & & \\
\hline & HedgShru & Hedges and/or shrubs & Yes & & \\
\hline & Meadow & Hay meadows & Yes & & \\
\hline & Pasture & Pastures & Yes & & \\
\hline & MeadPastTree & $\begin{array}{l}\text { Meadows and pastures with trees and/or } \\
\text { bushes }\end{array}$ & No & & \\
\hline & AnnCult & Annual crops & Yes & & \\
\hline & PermCult & Permanent crops & Yes & & \\
\hline & RocScr & Rock/ screen slopes & Yes & & \\
\hline & DecFor & Deciduous forests & Yes & & \\
\hline & ConFor & Coniferous forests & Yes & & \\
\hline & RipFor & Riparian forests & Yes & & \\
\hline & MixFor & Mixed forests & No & & \\
\hline & MountPine & Mountain pines & No & & \\
\hline & Rhod & Rhododendrons & No & & \\
\hline & Wet & Wetlands & Yes & & \\
\hline & LakRiv & Lakes and rivers & Yes & & \\
\hline & Roads & Roads, tracks and rail & Yes & & \\
\hline
\end{tabular}


Table 1 (continued)

\begin{tabular}{|c|c|c|c|c|c|}
\hline Type & Variable & Name & Included & Description & Unit \\
\hline \multirow[t]{5}{*}{ Configurational } & ED & Edge density & Yes & $\begin{array}{l}\text { Sum of the edges of all LULC classes } \\
\text { divided by the area of the buffer. It } \\
\text { includes buffer boundary segments } \\
\text { representing 'true' edge only (i.e., abutting } \\
\text { patches of different classes) }\end{array}$ & $\mathrm{m} \mathrm{ha}^{-1}$ \\
\hline & AREA_MN & Mean patch area & Yes & $\begin{array}{l}\text { Buffer area divided by the total number of } \\
\text { patches inside }\end{array}$ & ha \\
\hline & PR & Patch richness & Yes & $\begin{array}{l}\text { Number of different LULC? types present } \\
\text { within the buffer boundary }\end{array}$ & $\mathrm{n}$ \\
\hline & SHDI & Shannon diversity index & Yes & $\begin{array}{l}S H D I=-\sum_{i=1}^{m}\left(P_{i} * \ln P_{i}\right) \\
P_{i}=\text { proportion of the area occupied by } \\
\text { LULC type (class) } i\end{array}$ & index \\
\hline & SHEI & Shannon evenness index & No & $\begin{array}{l}S H E I=\frac{-\sum_{i=1}^{m}\left(P_{i} * \ln P_{i}\right)}{\ln m} \\
P_{i}=\text { proportion of the area occupied by } \\
\text { LULC type (class) } i \\
m=\text { number of LULC types (classes) } \\
\text { present in the area, excluding the buffer } \\
\text { border if present }\end{array}$ & \\
\hline
\end{tabular}

pattern at all, suggesting the lack of spatial autocorrelation. All the analyses were done with $\mathrm{R}$ version 3.4.1 (R Development Core Team 2019).

\section{Results}

The final dataset included 4,494 individuals belonging to 110 species. The Chaffinch (Fringilla coelebs) was the most observed species with a total of 330 individuals; some of the rarest were Corn crake (Crex crex), Little bittern (Ixobrychus minutus), and Eurasian three-toed woodpecker (Picoides tridactylus) which were recorded only once. At the species richest study site (a wetland), we counted 27 species, and at the poorest ones 3 species (three alpine sites). The accumulation curves indicated that the sampling was adequate and complete (Fig. S7 and Fig. S8).

\section{Modelling the effect of different drivers on avian communities}

At both spatial scales, and for all the dependent variables, the synthetic model had the overall lowest AICc (Table 2). Comparing the models containing only a single type of variables, again at both spatial scales and for all dependent variables, the models based on landscape compositional variables exhibited the lowest AICc. At the smaller scale the topo-climatical model, and at the larger scale the landscape configuration model were the most supported after the landscape compositional model.
According to the synthetic models, topo-climatical variables did not show consistent effects, apart from a negative impact of mean annual precipitation on all indices at the small scale (but note a positive effect on species richness at $400 \mathrm{~m}$ ).

For the compositional variables, Alpine grassland and summer pastures had positive effects on Fdis and negative ones on Shan and on Sric. Highly structured grasslands, hay meadows, and pastures always showed positive influences on Fdis and Sric. On the contrary, permanent crops exerted negative effects on all indices, while annual crops had positive effects on Fdis. Deciduous forests positively impacted Fdis, while hedges and shrubs, coniferous and riparian forests had negative effects. Lakes/rivers and wetlands had positive effects on all indices. Roads/tracks/rail positively affected Fdis and Shan, whereas urban areas had positive effect on Fids and negative on Shan.

Configurational variables included in the synthetic models were patch richness (with positive effects on Shan and Sric), and patch area (negative effects on Fdis and Shan). For a more complete interpretation see Table 3 and Table S4.

\section{Modelling environmental drivers on bird red-list categories}

In the fourth-corner analysis (Fig. 3) mean annual precipitation showed negative and positive associations, respectively, with endangered (EN) and vulnerable (VU) species at both scales. Open areas were associated with bird communities with many threatened species: hay 

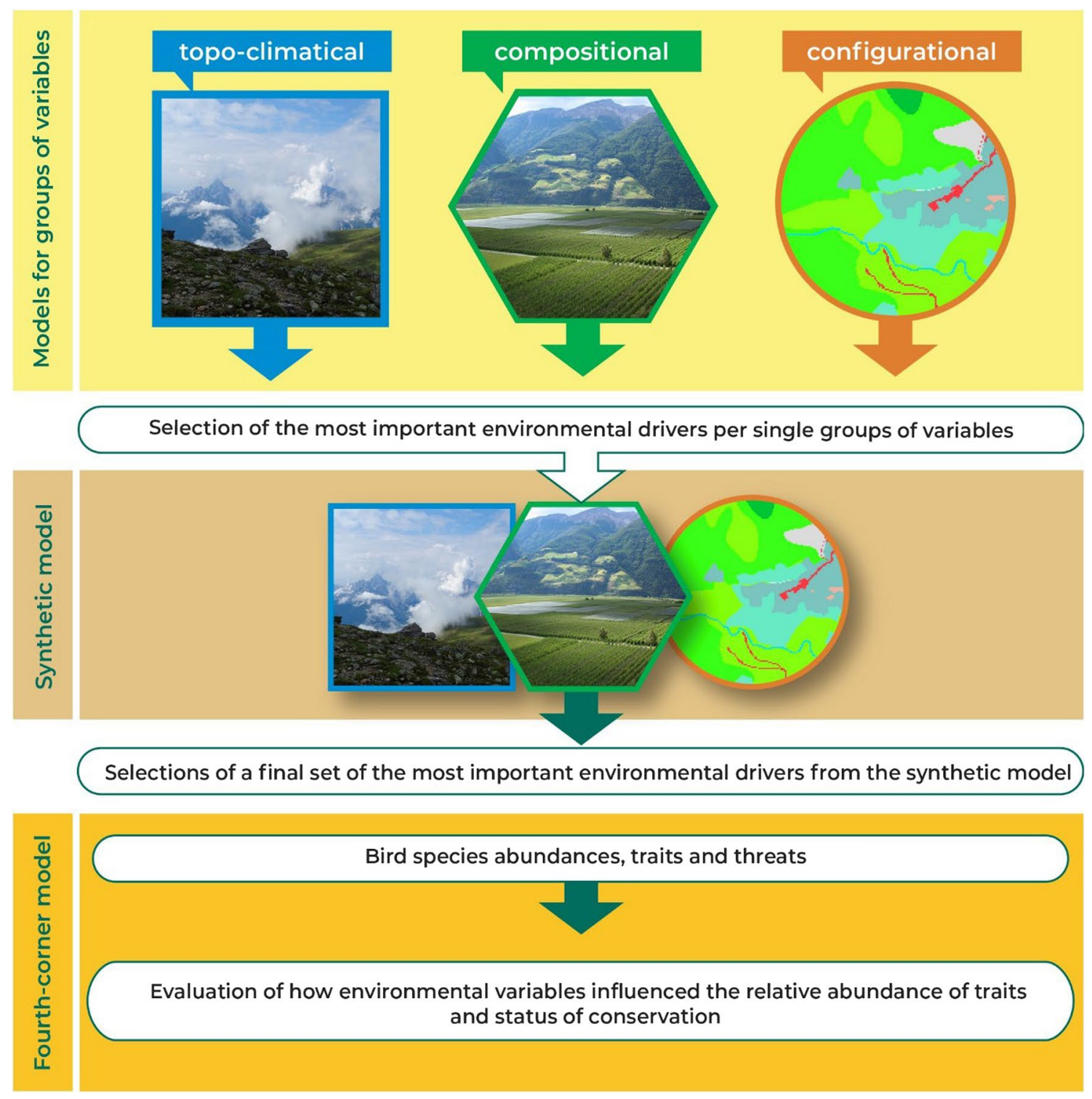

Fig. 2 Scheme showing the statistical framework adopted to evaluate the effects of different types of environmental variables (topo-climatical, LULC compositional, and configurational) on the three bird

meadows were positively related with critical endangered (CR) at both scales, with EN and VU respectively at large and small scales, and pastures with CR species at largest scale. Additionally, Alpine grasslands/summer pastures at both scales, and hay meadows at $400 \mathrm{~m}$, were negatively associated with least concern (LC) species. Annual crops were positively associated with EN and VU at both scales, negatively with LC at $400 \mathrm{~m}$, and moderately negatively at $100 \mathrm{~m}$. Lakes/rivers were associated with EN and near threatened (NT) species in at largest scale; wetlands with EN at small scale. Configurational variables did not show association with red-list categories. diversity indices (species richness, Shannon diversity and functional diversity), and on bird traits and red-list categories. This approach was used at two different spatial scales (100 and 400-m radii)

\section{Modelling environmental drivers on bird traits}

Environmental parameters associated with bird traits revealed rather unexpected results (Fig. 4). Annual crops were associated with low specialization at both scales. Non-sedentary species were abundant in permanent crops at both scales. Open area species were more strongly associated with Alpine grasslands/summer pastures at both scales. Shrubland specialist species occurred at both scales in annual crops. Forest species were positively associated with permanent crops at both scales, and with less patches at $100 \mathrm{~m}$, and larger mean patch area at $400 \mathrm{~m}$. A strong positive correlation emerged between permanent crops and 
Table 2 AICc and $R^{2}$ of synthetic models, and of models including only single type of environmental variables

\begin{tabular}{|c|c|c|c|c|}
\hline Scale & $\begin{array}{l}\text { Dependent } \\
\text { variable }\end{array}$ & Type of model & $\mathrm{AICc}$ & $\mathrm{R}^{2}$ \\
\hline \multirow[t]{12}{*}{$100 \mathrm{~m}$ radius } & \multirow[t]{4}{*}{ Sric } & Topo-climatical & 973.90 & \\
\hline & & Compositional & 917.08 & \\
\hline & & Configurational & 994.42 & \\
\hline & & Synthetic & 911.03 & 0.54 \\
\hline & \multirow[t]{4}{*}{ Shan } & Topo-climatical & 204.86 & \\
\hline & & Compositional & 162.33 & \\
\hline & & Configurational & 216.45 & \\
\hline & & Synthetic & 150.96 & 0.46 \\
\hline & \multirow[t]{4}{*}{ Fdis } & Topo-climatical & -582.88 & \\
\hline & & Compositional & -650.15 & \\
\hline & & Configurational & -578.9 & \\
\hline & & Synthetic & -651.04 & 0.47 \\
\hline \multirow[t]{12}{*}{$400 \mathrm{~m}$ radius } & \multirow[t]{4}{*}{ Sric } & Topo-climatical & 973.90 & \\
\hline & & Compositional & 887.82 & \\
\hline & & Configurational & 949.11 & \\
\hline & & Synthetic & 875 & 0.63 \\
\hline & \multirow[t]{4}{*}{ Shan } & Topo-climatical & 204.86 & \\
\hline & & Compositional & 141.05 & \\
\hline & & Configurational & 191.73 & \\
\hline & & Synthetic & 129.10 & 0.52 \\
\hline & \multirow[t]{4}{*}{ Fdis } & Topo-climatical & -582.88 & \\
\hline & & Compositional & -647.91 & \\
\hline & & Configurational & -595.10 & \\
\hline & & Synthetic & -653.06 & 0.45 \\
\hline
\end{tabular}

Data were grouped firstly for spatial scales, and secondly for dependent variables $($ Sric $=$ species richness, Shan $=$ Shannon diversity index, and Fdis = functional diversity index). For more details on all the most supported models $(\mathrm{AICc}<2)$ among all the possible ones see Table S3

birds mainly nesting in open woodlands, in bushes and trees, while species that nest on or close to the ground were fewer in permanent crops, and moderately common in open habitats. Considering diets, at both scales, birds that feed in the tree layer were negatively affected by permanent crops. Birds feeding on the ground were associated with annual and permanent crops, and with highly structured grasslands. Birds with a diet dominated by plants and seeds were associated with both annual and permanent crops.

\section{Discussion}

Investigating how drivers such as land use/land cover (LULC) composition and configuration, topography, and climate affect biological communities is essential to decipher which factors exert the strongest effect on biodiversity at different spatial scales. Here, we focused on bird communities considering three diversity indices (species richness, Shannon diversity, and functional diversity) across broad landscape gradients determined by elevation, topography, and local climate. Especially the functionality index allowed us to assess the diversity of the bird community beyond the simple species diversity at a site. The fourth-corner analysis evaluated the link between environmental drivers and threatened species and/or species with unique traits. Addressing the distribution of traits across different gradients to identify priority conservation action provides a more comprehensive assessment of the quality of an ecosystem and of the resilience of a bird community than species richness alone (Veach et al. 2017).

For all three diversity indices at both spatial scales, the synthetic model was the most supported one, denoting the concurrent effect of different environmental drivers. This is consistent with the importance of such predictors, and of the relative interactions, reported from studies focusing on less heterogeneous environments (Jongsomjit et al. 2013; Mantyka-Pringle et al. 2015), and in particular for Alpine bird communities (Chamberlain et al. 2016; Scridel et al. 2018). The LULC compositional model was invariably the most supported among the single-group models. LULC composition plays a crucial role in shaping local biodiversity and hence bird communities (Santana et al. 2017), even across such a broad environmental gradient. Topo-climatic models were also important, especially at the smaller scale, where the effect of topography and climate are likely to affect mesoclimatic conditions, while landscape configurational models were more important at the larger scale. These findings are especially relevant for many mountain systems, where land abandonment, management intensification, habitat fragmentation, as well as climate change, are posing severe threats to biodiversity (Chamberlain et al. 2016; Scridel et al. 2018) and are predicted to be the most impacting pressures also for the decades to come (Newbold 2018).

Topo-climatical drivers in the synthetic models mostly acted at the small scale. The only exception was mean annual precipitation, which positively affected bird species richness at the $400 \mathrm{~m}$ scale, while negatively impacting all three indices at the $100 \mathrm{~m}$ scale. The interaction between precipitation and topographical traits likely led to relevant variations of local climates. Climate predictors were highly intercorrelated; we retained precipitation in the models because in the Alps mean annual precipitation and continentality vary greatly with geographical location, with different patterns of variation along elevation gradients. Inner valleys are characterised by very continental climates, whereas other regions in the Alps, especially the peripheral ones, exhibit more oceanic climates, with much higher precipitation levels. This gradient is very pronounced also within our study area, with yearly precipitation ranging from c. $500 \mathrm{~mm}$ per year (Vinschgau) to $>1600 \mathrm{~mm}$ per year (Ulten Valley; Rubel et al. 
Table 3 Graphical representation of the responses of dependent variables to predictors in the synthetic models. "+" and "-" represent positive and negative effects, respectively (see Table 1 and S4, and Fig. S1-S6, for details)

\begin{tabular}{|c|c|c|c|c|c|c|c|}
\hline \multirow[t]{2}{*}{ Type of variables } & \multirow[t]{2}{*}{ Environmental variables } & \multicolumn{2}{|c|}{ Functional diversity } & \multicolumn{2}{|c|}{ Shannon diversity } & \multicolumn{2}{|c|}{ Species richness } \\
\hline & & $100-\mathrm{m}$ & $400-\mathrm{m}$ & $100-\mathrm{m}$ & $400-\mathrm{m}$ & $100-\mathrm{m}$ & $400-\mathrm{m}$ \\
\hline \multirow[t]{2}{*}{ Topo-climatical } & Potential solar radiation & -0.01 & & & & & \\
\hline & Mean annual precipitation sum & -0.01 & & -0.13 & & -0.02 & +0.05 \\
\hline \multirow[t]{15}{*}{ Compositional } & Alpine grasslands and summer pastures & +0.01 & & -0.13 & -0.19 & -0.13 & -0.16 \\
\hline & Rock/screen slopes & -0.002 & & -0.17 & -0.16 & -0.20 & -0.17 \\
\hline & Highly structured grasslands & +0.003 & +0.003 & & & & \\
\hline & Hay meadows & +0.02 & +0.02 & & & & +0.02 \\
\hline & Pastures & & & & & & +0.01 \\
\hline & Annual crops & +0.01 & +0.002 & -0.10 & -0.08 & & -0.03 \\
\hline & Permanent crops & -0.001 & & -0.12 & -0.05 & -0.06 & \\
\hline & Deciduous forests & +0.0006 & & & & & \\
\hline & Coniferous forests & -0.0005 & & & & & \\
\hline & Riparian forests & & -0.004 & & & & \\
\hline & Hedges and/or shrubs & -0.003 & -0.003 & & & & \\
\hline & Lakes and rivers & +0.007 & +0.01 & & +0.07 & +0.01 & +0.07 \\
\hline & Wetlands & +0.008 & & & & +0.05 & \\
\hline & Roads, tracks and rail & +0.004 & & +0.02 & & & \\
\hline & Urban areas & +0.02 & +0.02 & -0.12 & -0.10 & & \\
\hline \multirow[t]{2}{*}{ Configurational } & Patch richness & & & +0.05 & +0.10 & +0.07 & +0.12 \\
\hline & Mean patch area & -0.002 & -0.009 & & -0.03 & & \\
\hline
\end{tabular}

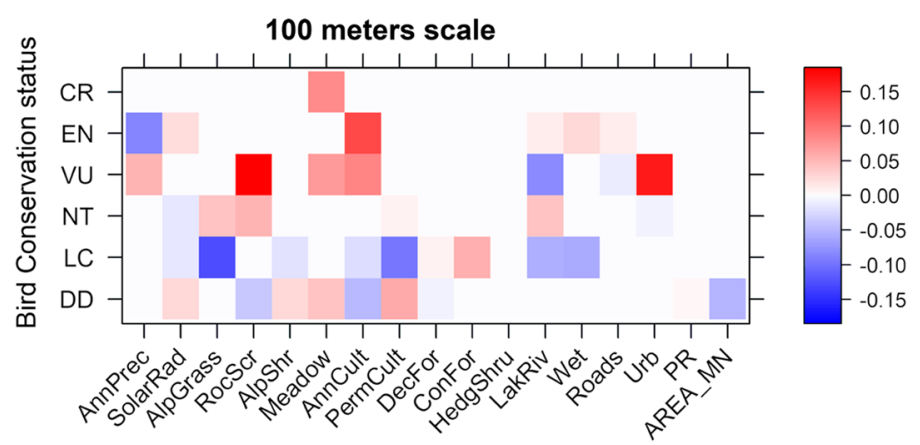

Environmental variables

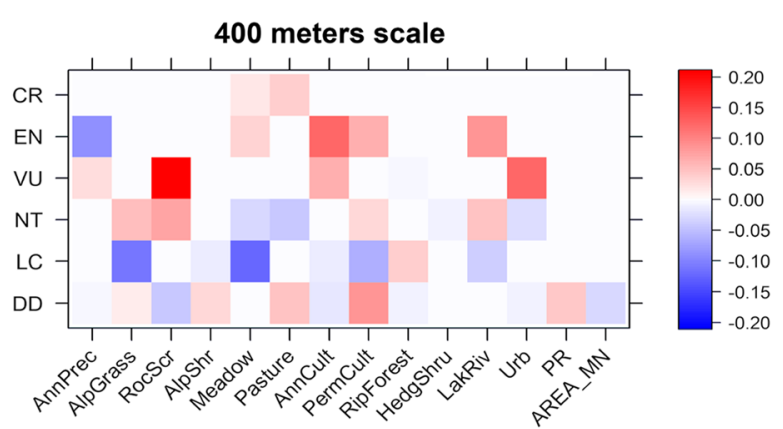

Environmental variables

Fig. 3 Relationships of red-list categories and environmental variables. Darker colours represent stronger associations (blue negative correlations, red positive ones). For red-list categories see the text; for variables see Table 1

2017). Furthermore, the fourth-corner analysis revealed a pattern of opposite association between endangered and vulnerable species with mean annual precipitation; in our study endangered species were found mainly at lower elevation and generally in drier valleys such as Dryobates minor and Sylvia communis, while vulnerable species were found generally in higher and wetter areas, such as Montifringilla nivalis and Cettia cetti.

LULC composition variables were abundant in the synthetic models, denoting their importance, particularly along gradients of very heterogeneous landscapes. The recent regional Red List of breeding birds reported for the study area that almost half of the bird species listed suffer from habitat destruction due to LULC change, disappearance of uncultivated areas, riparian vegetation and hedges, while another large portion of species suffers from intensive management of farmed areas. These findings were corroborated by our results. Alpine grasslands and summer pastures showed a positive relationship with functional diversity, probably because a relatively high number of specialist species, with very narrow ecological niches occur in these habitats, resulting in high functional diversity (Altamirano et al. 

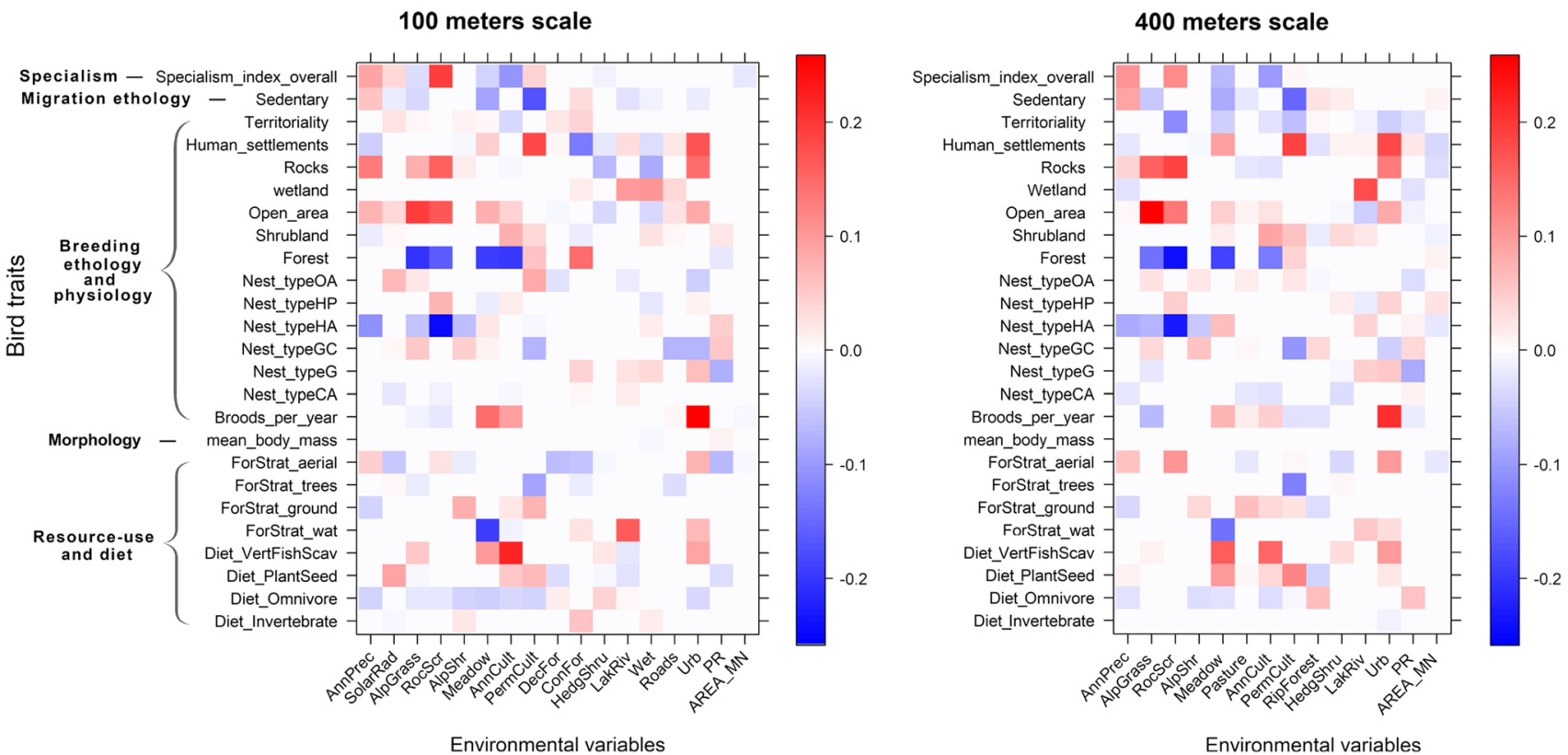

Fig. 4 Relationships between bird traits and environmental variables derived from the synthetic models. Darker colours represent stronger associations. Blue colour represents negative correlations; red colour represents positive ones. For bird traits see Table S1; for variables see Table 1

2020). Moreover, highly structured grasslands, hay meadows and pastures always showed positive effects on all diversity indices. This result demonstrated the overall importance of open areas, and of their management, for both functional and taxonomic bird diversity (Assandri et al. 2019). At both spatial scales, open-area habitats were most closely associated with threatened species, and negatively with non-threatened ones. The same is true for water-dominated habitats, which are rich in threatened species (Brusa et al. 2019; Morganti et al. 2019). Our synthetic models suggested that fresh-water habitats had strong positive influences on all dependent variables. Wetlands, lakes, and rivers are important hotspots of biodiversity in the Alpine region, representing key sites for bird conservation (Brusa et al. 2019). Therefore, preserving open areas and wetlands would not only increase species number/diversity and functional diversity in bird communities, but would also benefit a large proportion of threatened species. Annual crops were positively correlated with functional diversity and negatively with the other indices, while permanent crops had negative effects on all diversity indices. In the Alpine region, annual crop fields are mostly small-sized and often part of environmental mosaics, with natural or seminatural elements, showing positive effects on biodiversity (Ceresa et al. 2012). These mosaics offer more niches, increasing the functionality of the bird community. On the contrary, permanent crops are the most intensive agriculture in the region, being associated with a severe landscape homogenisation (Tasser et al. 2009), and thus harbour poorer bird communities. Annual crops were also positively associated with vulnerable and endangered bird species, consistently with the local status of farmland birds (Ceresa and Kranebitter 2020; Ceresa, et al. 2020a). In annual and permanent crops, birds mostly forage on the ground, feeding on plants and seeds, and mainly nest on open-arboreal areas, in bushes and trees. Heterogeneous agricultural landscapes, with more structural elements, and different LULC patches, are key to conserve avian communities in these landscapes. Coniferous forests negatively and deciduous forests positively affected functional diversity. Broadleaved forests are more heterogeneous and variable in the Alpine region, offering more and diverse niches for breeding birds (Winkler 2005). Our data suggested that forest specialists may avoid fragmented and discontinuous forests, preferring continuous forest areas, as more strongly evident in other studies about forest specialists (Bełcik et al. 2020). Hedges and shrubs, as well as riparian forests, had negative effects on functional diversity and hardly showed any critical effects on red-list categories and bird traits. In the study area, both habitats are predominantly found in depauperated landscapes, such as valley bottoms close to intensively managed agricultural areas. The negative effect associated with hedgerows is indeed likely due to their predominant occurrence in simplified agricultural landscapes of the study area; their occurrence may hence indicate an intensification context, not entirely captured by other variables. We do not believe that such a negative association is related to a true negative effect exerted by hedgerows. Riparian forests often suffer inadequate management, resulting in a very low degree of naturalness, and in the study area are often highly fragmented or highly urbanised, offering 
few ecological niches (Larsen 2017). Urban areas, mostly represented by small settlements or even single buildings, offer more niches and were positively related to functional diversity. Villages in agricultural areas or in heterogeneous landscapes increase landscape complexity (Tasser et al. 2009). Roads show a positive correlation with both functional diversity and taxonomic diversity (Shannon). This could be partially due to an increase in bird detectability along roads. However, roads, tracks, and rails often have an ecotonal effect on the surrounding landscapes (DánielFerreira et al. 2020) and are lined with narrow strips of embankments or shrubbery, providing potential habitats for birds (Coffin 2007).

Landscape configurational variables largely entered in our synthetic models at both scales, confirming the importance of such factors even along broad environmental gradients. This is a particularly important result, as assessments usually evaluate the potential importance of landscape configuration over homogeneous contexts, or at a single spatial scale. We found a strong and positive effect of the number of patches of different LULCs on Shannon diversity and bird species richness. Expectedly, a higher landscape heterogeneity resulted in a higher species diversity (Redlich et al. 2018). The mean patch area exerted a strongly negative effect on bird functional diversity: the more configurationally heterogeneous an area, the higher the number of species and functional groups that could be expected (Devictor and Jiguet 2007). This pattern is consistent with the mosaic concept (Duelli 1997), which theorises that highly heterogeneous landscapes can harbour a more diverse and specialised flora and fauna, and thus contribute to the overall diversity. This result shows that landscape heterogeneity is of great importance for bird communities in diverse areas such as the Alps.

\section{Conclusions}

For conservations strategies, we strongly recommend that landscapes surrounding agricultural and anthropogenic landscapes should be managed to maintain or (re)generate heterogeneous mosaics, with smaller and diversified patch sizes (avoiding larger continuous patches of single LULC). In that sense, some measures implemented in Rural Development Programmes of different Alpine regions, focusing on crop diversification and on the restoration of natural or seminatural habitats, such as ponds, shrub patches, grasslands, could provide an important contribution to this objective. On the other hand, in forest habitats efforts should be made to minimise habitat fragmentation by keeping woodlands as continuous as possible. The opposite association pattern between precipitation and endangered and vulnerable species, respectively, suggests that threatened species are associated with different climates, and hence conservation efforts need to encompass the broad climatic gradient. Strategies aimed at promoting birds and biodiversity in the Alpine region, undergoing dramatic changes, should acknowledge three key points. First, the importance of landscape heterogeneity in agricultural and anthropogenic areas should be promoted, giving priority to patches of open habitats and structural elements. In this sense, agricultural policies such as Rural Development Programmes could be crucial (Concepción et al. 2020; Rotchés-Ribalta et al. 2021). They should ideally consider the complementary effects of landscapes heterogeneity and the importance of small patch mosaics for the taxonomic and functional diversity of farmland birds. Second, the key role of wetlands must be recognized; their conservation and, where needed, restoration and proper management should be part of landscape and conservation strategies (see Morganti et al. 2019; Brambilla et al. 2020b, c for similar areas). Third, in the case of forest, habitat continuity and homogeneity are needed to support specialist bird species, and should be pursued by proper management and planning decisions.

Supplementary Information The online version contains supplementary material available at https://doi.org/10.1007/s00442-022-05134-7.

Acknowledgements We thank Thomas Marsoner for cartographic support. Francesco Ceresa (Museum of Nature South Tyrol) and Giacomo Assandri provided helpful comments and suggestions. We thank two anonymous reviewers for thorough and helpful reviews. The Department of Nature, Landscape and Spatial Development, in particular the Office of Nature, and to the Forestry Department provided logistic support. This work is part of M.A.'s PhD at the University of Innsbruck.

Author contribution statement $\mathrm{MA}, \mathrm{CP}, \mathrm{MB}, \mathrm{AH}$, UT conceived and designed the study. MA and SV collected data in the field. MA, MB, $\mathrm{CP}$ led the analyses and produced the figures. SV, supported by MA and ET, improved the LULC map, carried out the landscape metrics and produced Figure 1. All authors discussed the results, wrote, and contributed critically to analyses and revisions of the final manuscript and gave final approval for publication.

Funding Open access funding provided by University of Innsbruck and Medical University of Innsbruck. This work is part of the Biodiversity Monitoring South Tyrol (https://biodiversity.eurac.edu), financed by the Autonomous Province of Bozen/Bolzano-South Tyrol.

Data availability statement The datasets generated and analysed during the current study are available from the corresponding author on reasonable request.

\section{Declarations}

Conflict of interest The authors have no conflicts of interest to declare that are relevant to the content of this article.

Open Access This article is licensed under a Creative Commons Attribution 4.0 International License, which permits use, sharing, adaptation, distribution and reproduction in any medium or format, as long as you give appropriate credit to the original author(s) and the source, provide a link to the Creative Commons licence, and indicate if changes 
were made. The images or other third party material in this article are included in the article's Creative Commons licence, unless indicated otherwise in a credit line to the material. If material is not included in the article's Creative Commons licence and your intended use is not permitted by statutory regulation or exceeds the permitted use, you will need to obtain permission directly from the copyright holder. To view a copy of this licence, visit http://creativecommons.org/licenses/by/4.0/.

\section{References}

Altamirano TA, de Zwaan DR, Ibarra JT et al (2020) Treeline ecotones shape the distribution of avian species richness and functional diversity in south temperate mountains. Sci Rep 10:18428. https:// doi.org/10.1038/s41598-020-75470-2

Amini Tehrani N, Naimi B, Jaboyedoff M (2020) Toward community predictions: Multi-scale modelling of mountain breeding birds' habitat suitability, landscape preferences, and environmental drivers. Ecol Evol 10:5544-5557. https://doi.org/10.1002/ece3.6295

Arnold TW (2010) Uninformative parameters and model selection using Akaike's information criterion. J Wildl Manag 74:11751178. https://doi.org/10.2193/2009-367

Assandri G, Bogliani G, Pedrini P, Brambilla M (2017a) Insectivorous birds as 'non-traditional' flagship species in vineyards: applying a neglected conservation paradigm to agricultural systems. Ecol Indic 80:275-285. https://doi.org/10.1016/j.ecolind.2017.05.012

Assandri G, Bogliani G, Pedrini P, Brambilla M (2017b) Land-use and bird occurrence at the urban margins in the Italian Alps: Implications for planning and conservation. North-West J Zool 13:77-84

Assandri G, Bogliani G, Pedrini P, Brambilla M (2019) Toward the next common agricultural policy reform: determinants of avian communities in hay meadows reveal current policy's inadequacy for biodiversity conservation in grassland ecosystems. J Appl Ecol 56:604-617. https://doi.org/10.1111/1365-2664.13332

Barnosky AD, Matzke N, Tomiya S et al (2011) Has the Earth's sixth mass extinction already arrived? Nature 471:51-57. https://doi. org/10.1038/nature09678

Barras AG, Braunisch V, Arlettaz R (2021) Predictive models of distribution and abundance of a threatened mountain species show that impacts of climate change overrule those of land use change. Divers Distrib 27:989-1004. https://doi.org/10.1111/ddi.13247

Barton K (2020) MuMIn: multi-model inference. R Package Version 1(43): 17

Bełcik M, Lenda M, Amano T, Skórka P (2020) Different response of the taxonomic, phylogenetic and functional diversity of birds to forest fragmentation. Sci Rep 10:20320. https://doi.org/10.1038/ s41598-020-76917-2

Bibby CJ (ed) (2000) Bird census techniques, 2nd edn. Academic, London

BirdlifeInternational (2020) BirdLife International (2020) IUCN Red List for birds. http://www.birdlife.org

BMS (2021) Biodiversity monitoring south tyrol. https://biodiversity. eurac.edu. Accessed 4 Sept 2021

Bocca M, Carisio L, Rolando A (2007) Habitat use, home ranges and census techniques in the black woodpecker Dryocopus martius in the Alps. Ardea 95:17-29. https://doi.org/10.5253/078.095.0103

Brambilla M (2019) Six (or nearly so) big challenges for farmland bird conservation in Italy. Avocetta 43:101-113. https://doi.org/ 10.30456/AVO.2019201

Brambilla M, Ficetola GF (2012) Species distribution models as a tool to estimate reproductive parameters: a case study with a passerine bird species: distribution models and reproductive parameters. J Anim Ecol 81:781-787. https://doi.org/10.1111/j.1365-2656. 2012.01970.x
Brambilla M, Gustin M, Cento M et al (2019) Predicted effects of climate factors on mountain species are not uniform over different spatial scales. J Avian Biol 50:2162. https://doi.org/10.1111/ jav.02162

Brambilla M, Gustin M, Cento M et al (2020a) Habitat, climate, topography and management differently affect occurrence in declining avian species: implications for conservation in changing environments. Sci Total Environ 742:140663. https://doi.org/10.1016/j. scitotenv.2020.140663

Brambilla M, Rizzolli F, Franzoi A et al (2020b) A network of small protected areas favoured generalist but not specialized wetland birds in a 30-year period. Biol Conserv 248:108699. https://doi. org/10.1016/j.biocon.2020.108699

Brambilla M, Scridel D, Bazzi G et al (2020c) Species interactions and climate change: how the disruption of species co-occurrence will impact on an avian forest guild. Glob Change Biol 26:1212-1224. https://doi.org/10.1111/gcb.14953

Brown AM, Warton DI, Andrew NR et al (2014) The fourth-corner solution-using predictive models to understand how species traits interact with the environment. Methods Ecol Evol 5:344 352. https://doi.org/10.1111/2041-210X.12163

Brusa G, Fratte MD, Bogliani G et al (2019) Le aree umide nella regione biogeografica Continentale dell'Italia settentrionale: Dagli scenari di cambiamento a prospettive di conservazione. Nat Hist Sci 6:37-69. https://doi.org/10.4081/nhs.2019.427

Bryant AA, Savard JPL, McLaughlin RT (1993) Avian communities in old-growth and managed forests of western Vancouver Island, British Columbia. Delta, BC: Canadian Wildlife Service

Burgess EE, Maron M (2016) Does the response of bird assemblages to fire mosaic properties vary among spatial scales and foraging guilds? Landsc Ecol 31:687-699. https://doi.org/10.1007/ s10980-015-0275-4

Burnham KP, Anderson DR (2004) Multimodel inference: understanding AIC and BIC in model selection. Sociol Methods Res 33:261304. https://doi.org/10.1177/0049124104268644

Cabral JP, Faria D, Morante-Filho JC (2021) Landscape composition is more important than local vegetation structure for understory birds in cocoa agroforestry systems. For Ecol Manag 481:118704. https://doi.org/10.1016/j.foreco.2020.118704

Cade BS (2015) Model averaging and muddled multimodel inferences. Ecology 96:2370-2382. https://doi.org/10.1890/14-1639.1

Ceresa F, Kranebitter P (2020) Lista Rossa 2020 degli uccelli nidificanti in Alto Adige. Gredleriana 20:57-70. https://doi.org/10. 5281/zenodo.4245030

Ceresa F, Bogliani G, Pedrini P, Brambilla M (2012) The importance of key marginal habitat features for birds in farmland: an assessment of habitat preferences of Red-backed Shrikes Lanius collurio in the Italian Alps. Bird Study 59:327-334. https://doi.org/10.1080/ 00063657.2012 .676623

Ceresa F, Anderle M, Hilpold L et al (2020a) Current distribution and population size of the Barred Warbler Sylvia nisoria in South Tyrol (Italy). Avocetta 44:1. https://doi.org/10.30456/AVO.2020a 101

Ceresa F, Brambilla M, Monrós JS et al (2020b) Within-season movements of Alpine songbird distributions are driven by fine-scale environmental characteristics. Sci Rep 10:5747. https://doi.org/ 10.1038/s41598-020-62661-0

Ceresa F, Kranebitter P, Monros S et al (2021) Disentangling direct and indirect effects of local temperature on abundance of mountain birds and implications for understanding global change impacts. PeerJ 9:e12560. https://doi.org/10.7717/peerj.12560

Chamberlain DE, Pedrini P, Brambilla M et al (2016) Identifying key conservation threats to Alpine birds through expert knowledge. PeerJ 4:e1723. https://doi.org/10.7717/peerj.1723 
Coffin AW (2007) From roadkill to road ecology: a review of the ecological effects of roads. J Transp Geogr 15:396-406. https://doi. org/10.1016/j.jtrangeo.2006.11.006

Concepción ED, Aneva I, Jay M et al (2020) Optimizing biodiversity gain of European agriculture through regional targeting and adaptive management of conservation tools. Biol Conserv 241:108384. https://doi.org/10.1016/j.biocon.2019.108384

Dániel-Ferreira J, Bommarco R, Wissman J, Öckinger E (2020) Linear infrastructure habitats increase landscape-scale diversity of plants but not of flower-visiting insects. Sci Rep. https://doi.org/10.1038/ s41598-020-78090-y

de Chazal J, Rounsevell MDA (2009) Land-use and climate change within assessments of biodiversity change: a review. Glob Environ Chang 19:306-315. https://doi.org/10.1016/j.gloenvcha.2008.09. 007

Debinski DM, Ray C, Saveraid EH (2001) Species diversity and the scale of the landscape mosaic: do scales of movement and patch size affect diversity? Biol Conserv 98:179-190. https://doi.org/ 10.1016/S0006-3207(00)00153-1

Devictor V, Jiguet F (2007) Community richness and stability in agricultural landscapes: the importance of surrounding habitats. Agric Ecosyst Environ 120:179-184. https://doi.org/10.1016/j.agee. 2006.08.013

Doley D (2010) The response of forests to climate change: the role of silviculture in conserving threatened species. Aust for 73:115125. https://doi.org/10.1080/00049158.2010.10676317

Dormann CF, McPherson JM, Araújo MB et al (2007) Methods to account for spatial autocorrelation in the analysis of species distributional data: a review. Ecography 30:609-628. https://doi.org/ 10.1111/j.2007.0906-7590.05171.x

Dormann CF, Elith J, Bacher S et al (2013) Collinearity: a review of methods to deal with it and a simulation study evaluating their performance. Ecography 36:27-46. https://doi.org/10.1111/j. 1600-0587.2012.07348.x

Duelli P (1997) Biodiversity evaluation in agricultural landscapes: an approach at two different scales. Agric Ecosyst Environ 62:81-91. https://doi.org/10.1016/S0167-8809(96)01143-7

Fahrig L, Baudry J, Brotons L et al (2011) Functional landscape heterogeneity and animal biodiversity in agricultural landscapes. Ecol Lett 14:101-112. https://doi.org/10.1111/j.1461-0248.2010. 01559.x

Flynn DFB, Gogol-Prokurat M, Nogeire T et al (2009) Loss of functional diversity under land use intensification across multiple taxa. Ecol Lett 12:22-33. https://doi.org/10.1111/j.1461-0248. 2008.01255.x

Fornasari L, Mingozzi T (1999) Monitoraggio dell'avifauna nidificante in Italia: un progetto pluriennale sulle specie comuni. Avocetta 23:153

GRASS Development Team (2020) Geographic Resources Analysis Support System (GRASS) Software. Open Source Geospatial Foundation Project. http://grass.osgeo.org [Accesed 15 Aug 2014].

Hsieh TC, Ma KH, Chao A (2016) iNEXT: an R package for rarefaction and extrapolation of species diversity ( $\mathrm{H}$ ill numbers). Methods Ecol Evol 7:1451-1456. https://doi.org/10.1111/2041-210X. 12613

Jacoboski LI, Hartz SM (2020) Using functional diversity and taxonomic diversity to assess effects of afforestation of grassland on bird communities. Perspect Ecol Conserv 18:103-108. https://doi. org/10.1016/j.pecon.2020.04.001

Jenkins CN, Pimm SL, Joppa LN (2013) Global patterns of terrestrial vertebrate diversity and conservation. Proc Natl Acad Sci 110:E2602-E2610. https://doi.org/10.1073/pnas.1302251110

Jongsomjit D, Stralberg D, Gardali T et al (2013) Between a rock and a hard place: the impacts of climate change and housing development on breeding birds in California. Landsc Ecol 28:187200. https://doi.org/10.1007/s10980-012-9825-1

Kim JH, Park S, Kim SH et al (2020) Structural implications of traditional agricultural landscapes on the functional diversity of birds near the Korean Demilitarized Zone. Ecol Evol. https://doi.org/ 10.1002/ece3.6880

Kujawa K, Wuczyński A, Dajdok Z, Grzesiak W (2020) Effect of habitat structure and crop diversity on common and threatened birds breeding in semi-natural field margins. Acta Ornithol 54:181. https://doi.org/10.3161/00016454AO2019.54.2.005

Laliberté E, Legendre P, Shipley B, Laliberté ME (2014) Package 'FD'. Measuring functional diversity (FD) from multiple traits, and other tools for functional ecology

Laliberté E, Legendre P (2010) A distance-based framework for measuring functional diversity from multiple traits. Ecology 91:299_ 305. https://doi.org/10.1890/08-2244.1

Larsen C (2017) Descrizione degli habitat dell'Alto Adige. Provincia Autonoma di Bolzano-Alto Adige, Ripartizione Natura, paesaggio e sviluppo del territorio. http://www.provincia.bz.it/natura-ambie nte/natura-territorio/costruire/tutela-insiemi.asp. Accessed 11 Dec 2020

Lee MB, Martin JA (2017) Avian species and functional diversity in agricultural landscapes: does landscape heterogeneity matter? PLoS ONE 12:e0170540. https://doi.org/10.1371/journal.pone. 0170540

Liu C, Dudley KL, Xu Z-H, Economo EP (2018) Mountain metacommunities: climate and spatial connectivity shape ant diversity in a complex landscape. Ecography 41:101-112. https://doi.org/10. 1111/ecog.03067

Mantyka-Pringle CS, Visconti P, Di Marco M et al (2015) Climate change modifies risk of global biodiversity loss due to land-cover change. Biol Conserv 187:103-111. https://doi.org/10.1016/j. biocon.2015.04.016

McGarigal K (2015) FRAGSTATS Help, Version 4.2. University of Massachusetts Amherst

Morganti M, Manica M, Bogliani G et al (2019) Multi-species habitat models highlight the key importance of flooded reedbeds for inland wetland birds: implications for management and conservation. Avian Res 10:15. https://doi.org/10.1186/s40657-019-0154-9

Newbold T (2018) Future effects of climate and land-use change on terrestrial vertebrate community diversity under different scenarios. Proc R Soc B Biol Sci 285:20180792. https://doi.org/10.1098/ rspb.2018.0792

Newbold T, Hudson LN, Hill SLL et al (2015) Global effects of land use on local terrestrial biodiversity. Nature 520:45-50. https://doi. org/10.1038/nature 14324

Noss RF, Cooperrider AY (1994) Saving nature's legacy: protecting and restoring biodiversity. Island Press, Washington, D.C.

Oksanen J, Blanchet FG, Kindt R et al (2020) Package 'vegan.' Commun Ecol Pack Version 2(5-7):1-298

Payne D, Spehn EM, Snethlage M, Fischer M (2017) Opportunities for research on mountain biodiversity under global change. Curr Opin Environ Sustain 29:40-47. https://doi.org/10.1016/j.cosust. 2017.11.001

Pecher C, Tasser E, Walde J, Tappeiner U (2013) Typology of Alpine region using spatial-pattern indicators. Ecol Indic 24:37-47. https://doi.org/10.1016/j.ecolind.2012.05.025

Pestka Z, Jakubas D, Wojczulanis-Jakubas K (2018) Habitat preferences of Red-backed Shrikes Lanius collurio and Barred Warblers Sylvia nisoria breeding sympatrically in a wetland/farmland mosaic. Bird Study 65:317-328. https://doi.org/10.1080/00063 657.2018.1503996

QGIS Development Team (2020) QGIS geographic information system. open source geospatial foundation. http://qgis.osgeo.org

R Development Core Team R (2019) R: a language and environment for statistical computing. R Found Stat Comput 1:409 
Redlich S, Martin EA, Wende B, Steffan-Dewenter I (2018) Landscape heterogeneity rather than crop diversity mediates bird diversity in agricultural landscapes. PLoS ONE 13:e0200438. https://doi.org/ 10.1371/journal.pone.0200438

Regan EC, Santini L, Ingwall-King L et al (2015) Global trends in the status of bird and mammal pollinators. Conserv Lett 8:397-403. https://doi.org/10.1111/conl.12162

Rotchés-Ribalta R, Ruas S, Ahmed KD et al (2021) Assessment of semi-natural habitats and landscape features on Irish farmland: new insights to inform EU common agricultural policy implementation. Ambio 50:346-359. https://doi.org/10.1007/ s13280-020-01344-6

Rubel F, Brugger K, Haslinger K, Auer I (2017) The climate of the European Alps: shift of very high resolution Köppen-Geiger climate zones 1800-2100. Meteorol Z 26:115-125. https://doi.org/ $10.1127 /$ metz/2016/0816

Rüdisser J, Tasser E, Tappeiner U (2012) Distance to nature-a new biodiversity relevant environmental indicator set at the landscape level. Ecol Indic 15:208-216. https://doi.org/10.1016/j.ecolind. 2011.09.027

Santana J, Reino L, Stoate C et al (2017) Combined effects of landscape composition and heterogeneity on farmland avian diversity. Ecol Evol 7:1212-1223. https://doi.org/10.1002/ece3.2693

Scridel D, Brambilla M, Martin K et al (2018) A review and metaanalysis of the effects of climate change on Holarctic mountain and upland bird populations. Ibis 160:489-515. https://doi.org/ 10.1111/ibi.12585

Scekercioğlu C, Wenny DG, Whelan CJ, (ed) (2016) Why birds matter: avian ecological function and ecosystem services. The University of Chicago Press, Chicago

Siriwardena GM, Henderson IG, Noble DG, Fuller RJ (2019) How can assemblage structure indices improve monitoring of change in bird communities using ongoing survey data? Ecol Indic 104:669685. https://doi.org/10.1016/j.ecolind.2019.05.046

Sutherland WJ (ed) (2006) Ecological census techniques: a handbook, 2nd edn. Cambridge University Press, Cambridge
Tasser E, Walde J, Tappeiner U et al (2007) Land-use changes and natural reforestation in the Eastern Central Alps. Agric Ecosyst Environ 118:115-129. https://doi.org/10.1016/j.agee.2006.05.004

Tasser E, Ruffini FV, Tappeiner U (2009) An integrative approach for analysing landscape dynamics in diverse cultivated and natural mountain areas. Landsc Ecol 24:611-628. https://doi.org/10.1007/ s10980-009-9337-9

Veach V, Di Minin E, Pouzols FM, Moilanen A (2017) Species richness as criterion for global conservation area placement leads to large losses in coverage of biodiversity. Divers Distrib 23:715-726. https://doi.org/10.1111/ddi.12571

Villard M-A, Trzcinski MK, Merriam G (1999) Fragmentation effects on forest birds: relative influence of woodland cover and configuration on landscape occupancy. Conserv Biol 13:774-783. https:// doi.org/10.1046/j.1523-1739.1999.98059.x

Wang Y, Naumann U, Wright ST, Warton DI (2012) mvabund - an $\mathrm{R}$ package for model-based analysis of multivariate abundance data. Methods Ecol Evol 3:471-474. https://doi.org/10.1111/j. 2041-210X.2012.00190.x

Wiktander U, Olsson O, Nilsson SG (2001) Seasonal variation in home-range size, and habitat area requirement of the lesser spotted woodpecker (Dendrocopos minor) in southern Sweden. Biol Conserv 100:387-395. https://doi.org/10.1016/S0006-3207(01) 00045-3

Winkler D (2005) Ecological succession of breeding bird communities in deciduous and coniferous forests in the Sopron Mountains, Hungary. Acta Silv Lignaria Hung 1:49-58

Zuur AF, Ieno EN, Walker N et al (2009) Mixed effects models and extensions in ecology with R. Springer, New York

Zuur AF, Ieno EN, Elphick CS (2010) A protocol for data exploration to avoid common statistical problems. Methods Ecol Evol 1:3-14. https://doi.org/10.1111/j.2041-210X.2009.00001.x

Zuur AF, Hilbe JM, Ieno EN (2013) A Beginner's Guide to GLM and GLMM with R. A frequentist and Bayesian perspective for ecologists. Highland Statistics Ltd, Newburgh 